\title{
HECTD2, a candidate susceptibility gene for Alzheimer's disease on IOq
}

\author{
Sarah E Lloyd*1,2, Martin Rossor ${ }^{2}$, Nick Fox ${ }^{2}$, Simon Mead ${ }^{1,2}$ and \\ John Collinge ${ }^{1,2}$
}

\begin{abstract}
Address: ${ }^{1}$ MRC Prion Unit, Department of Neurodegenerative Disease, UCL Institute of Neurology, London, WC1N 3BG, UK and ${ }^{2}$ Department of Neurodegenerative Disease, UCL Institute of Neurology, London, WC1N 3BG, UK

Email: Sarah E Lloyd* - s.lloyd@prion.ucl.ac.uk; Martin Rossor - m.rossor@drc.ion.ucl.ac.uk; Nick Fox - n.fox@ucl.ac.uk; Simon Mead - s.mead@prion.ucl.ac.uk; John Collinge - j.collinge@prion.ucl.ac.uk

* Corresponding author
\end{abstract}

Published: 15 September 2009

BMC Medical Genetics 2009, 10:90 doi:10.1 186/147/-2350-10-90

This article is available from: http://www.biomedcentral.com/I47I-2350/I0/90

(C) 2009 Lloyd et al; licensee BioMed Central Ltd.

This is an Open Access article distributed under the terms of the Creative Commons Attribution License (http://creativecommons.org/licenses/by/2.0), which permits unrestricted use, distribution, and reproduction in any medium, provided the original work is properly cited.
Received: 2 June 2009

Accepted: 15 September 2009

\begin{abstract}
Background: Late onset Alzheimer's disease (LOAD) is a neurodegenerative disorder characterised by the deposition of amyloid plaques and neurofibrillary tangles in the brain and is the major cause of dementia. Multiple genetic loci, including $10 \mathrm{q}$, have been implicated in LOAD but to date, with the exception of APOE, the underlying genes have not been identified. HECTD2 maps to $\mathrm{IO} \mathrm{q}$ and has been implicated in susceptibility to human prion diseases which are also neurodegenerative conditions associated with accumulation of misfolded host proteins. In this study we test whether the HECTD2 susceptibility allele seen in prion disease is also implicated in LOAD.
\end{abstract}

Methods: DNA from 320 individuals with Alzheimer's disease and 60I controls were genotyped for a HECTD2 intronic tagging SNP, rs/2249854 (A/T). Groups were further analysed following stratification by APOE genotype.

Results: The rs / 2249854 minor allele (A) frequency was higher (5.8\%) in the Alzheimer's disease group as compared to the controls $(3.9 \%)$, however, this was not statistically significant $(\mathrm{P}=$ 0.0668 ). No significant difference was seen in minor allele frequency in the presence or absence of the APOE $\varepsilon 4$ allele.

Conclusion: The common haplotypes of HECTD2, tagged by rs / 2249854, are not associated with susceptibility to LOAD.

\section{Background}

Alzheimer's disease (AD) is the most common form of dementia affecting millions of people worldwide [1]. The decline in cognitive ability is accompanied by characteristic pathological changes in the brain which include deposition of extracellular amyloid plaques composed of $\beta$ amyloid $(\mathrm{A} \beta)[2]$ and the accumulation of intracellular neurofibrillary tangles (hyperphosphorylated tau) [3]. Mutations in three genes, $\beta$-amyloid precursor protein $(A P P)$, presenilin-1 (PSEN1) and presenilin-2 (PSEN2), have been found in early-onset autosomal dominant $\mathrm{AD}$ [4-6]. In contrast, the majority of $\mathrm{AD}$ cases have a later age of onset ( $>65$ years) [1] and although heritability is high, there are multiple environmental and genetic risk factors 
with no clear Mendelian pattern of inheritance [7]. To date, the main genetic risk factor for late onset Alzheimer's disease (LOAD) is the apolipoprotein $\mathrm{E}$ gene (APOE) where the $\varepsilon 4$ allele is over-represented in affected individuals $(50 \%)$ compared to controls [8]. The partial penetrance for $\varepsilon 4$ suggests that other genes are also likely to be important in the development of LOAD [9].

Linkage studies, and more recently genome-wide association studies (GWAS), have provided evidence to support a role for multiple genes in the aetiology of $\operatorname{LOAD}[9,10]$. Difficulties in replicating findings across multiple studies still leaves considerable uncertainty in defining the genetic risk factors. Significant evidence exists for a susceptibility locus on chromosome 10q [11-14], however, there are conflicting reports on its precise location and to date no clear association to an individual gene has been demonstrated. Insulin degrading enzyme (IDE) is encoded by a gene that maps to Chr 10q and has been implicated in the breakdown and clearance of extracellular $A \beta[15]$. Although there is contradictory evidence for an allelic association between IDE and AD [16-18] a linkage study carried out in 435 multiplex AD families found significant linkage to markers adjacent to IDE (D10S583 and D10S1671) [11,19].

HECTD2 encodes an E3-ubiquitin ligase protein and maps within $1 \mathrm{Mb}$ of D10S583 and IDE. HECTD2 has been linked to prion disease incubation time in mice and a susceptibility haplotype has been associated with human prion disease [20]. Prion diseases, like AD, are neurodegenerative disorders with a complex aetiology. Mutations in the prion protein gene (PRNP) cause the inherited prion diseases $[21,22]$ and coding polymorphisms in the prion protein (PrP) are associated with susceptibility to acquired and sporadic Creutzfeldt-Jakob disease (CJD), kuru and influence age of onset in some inherited prion diseases [23-25]. Similarly to LOAD, acquired and sporadic CJD have a complex non-Mendelian genetic component where there is evidence for the role of multiple genes [26-29]. Prion diseases also share some of the neuropathologic hallmarks of $\mathrm{AD}$ and are considered to be diseases of protein misfolding where abnormal forms of PrP accumulate in the brain often in the form of amyloid plaques $[21,30]$.

The similarities between $\mathrm{AD}$, prion diseases and other neurodegenerative disorders suggest that common molecular mechanisms and pathways may be involved. The ubiquitin-proteosome system is one such example that has been implicated in the pathogenesis of several neurodegenerative diseases which show an accumulation of an abnormally folded protein including $\mathrm{AD}$ and prion disease [31-33]. The substrate and exact function of HECTD2 are unknown but by homology to other family members it is thought to function as an E3 ubiquitin ligase, catalysing the transfer of ubiquitin to specific proteins, thus targeting them for degradation by the proteosome. Mutations in an E3 ubiquitin ligase, parkin, are associated with forms of inherited Parkinson's disease [34].

The location of HECTD2 on Chr 10q, its association with another neurodegenerative proteinopathy and its involvement in the ubiquitin-proteosome pathway suggest that HECTD2 is a suitable candidate gene for LOAD susceptibility. The aim of this study was therefore to test whether the HECTD2 risk allele seen in CJD is also a susceptibility factor for non-familial AD.

\section{Methods \\ Human samples}

The clinical and laboratory studies were approved by the local research ethics committee of University College London Institute of Neurology and National Hospital for Neurology and Neurosurgery. Most of the samples were obtained with written consent from patients or next of kin, however, for archival samples, where this was not available, specific approval was obtained from the local ethics committee.

\section{Alzheimer's disease}

Patient samples were derived from the MRC Prion Unit sample collection based on a clinician's diagnosis of $\mathrm{AD}$ $(\mathrm{n}=320)$. The majority of samples were referred to the Unit for APP, PSEN1 or PSEN2 gene sequencing although not all genes were tested in all patients, because for example, some samples were referred prior to the discovery of presenilin gene mutations as causal in AD. Samples with causal mutations were excluded. Consequent upon patient ascertainment, the sample collection is enriched for unexplained early onset AD. Those of known nonwhite Caucasian ethnicity were excluded. Average age at time of sampling was 53, 47\% were male. Ethical approval for the study was given by the University College London Hospitals NHS Trust Local Ethics Committee. APOE genotypes were obtained for $\mathrm{n}=316$ samples. Allele frequencies for $\varepsilon 2, \varepsilon 3$ and $\varepsilon 4$ were $3.6 \%, 62.1 \%$ and $34.3 \%$ respectively. $55.1 \%$ of individuals had one or more $\varepsilon 4$ alleles which is consistent with other reports of LOAD.

\section{UK controls}

116 individuals were recruited from the National Blood Service (NBS). Individuals were of white-British ethnicity and the mean of age at sampling was 34 years (range 18$64) ; 56 \%$ were male. DNA was extracted from whole blood. Further UK control samples $(\mathrm{n}=485)$ were purchased from the European Collection of Cell Cultures (ECACC) Human Random control (HRC) DNA panels consisting of randomly selected, non-related UK Cauca- 
sian blood donors. Total number of UK controls was $\mathrm{n}=$ 601.

\section{DNA extraction}

Genomic DNA was usually extracted from peripheral blood using a Nucleon Genomic DNA Extraction Kit according to the manufacturer's instructions; for a small number of brain tissue samples we used a phenol-chloroform method. Amplified DNA, using either multiple displacement amplification (Geneservice, Cambridge, UK) or fragmentation-PCR methods (Genomeplex, Sigma), was used for a small number $<10 \%$ of samples. Samples were checked for degradation on $1 \%$ agarose gel and stored at $50 \mathrm{ng} / \mu \mathrm{l}$ in $10 \mathrm{mM}$ Tris-EDTA buffer.

\section{Genotyping}

For $r$ 12249854 a pre-designed allelic discrimination assay was purchased from Applied Biosystems and used according to the manufacturer's instructions. All reactions were carried out in $5 \mu \mathrm{l}$ on a 7500 Fast Real-time PCR System (Applied Biosystems) using RoxMegaMix Gold (Microzone Ltd). Cycling conditions were $95^{\circ} \mathrm{C} 5$ minutes; $95^{\circ} \mathrm{C}$ $15 \mathrm{~s}, 60^{\circ} \mathrm{C} 60 \mathrm{~s}$ for 40 cycles.

\section{APOE genotyping}

$A P O E$ genotyping was performed by Cfo1 restriction endonuclease digestion of PCR amplicon and size differentiation by agarose gel electrophoresis [35].

\section{Statistical genetics}

Association was tested using the Pearson Chi-squared test (SPSS, SPSS Inc.). Additional permutation tests were carried out using PLINK [36].

\section{Results}

We have previously shown that strong linkage disequilibrium (LD) extends across the whole of the HECTD2 gene and interrogation of HapMap data suggests that this block of LD does not extend into neighbouring genes [20]. It is therefore possible to tag the haplotype associated with susceptibility to prion disease with a single nucleotide polymorphism (SNP), rs12249854 (A/T) that occurs within intron 1 of HECTD2. rs12249854 was genotyped in a panel of 320 samples from patients with a definite or probable diagnosis of $\mathrm{AD}$ and no known mutations in APP, PSEN1 or PSEN2. APOE genotypes were available for 316 individuals and showed enrichment for the $\varepsilon 4$ allele ( $55.1 \%$ of individual have one or more $\varepsilon 4$ allele). Genotypes were compared with those of a previously genotyped UK control group $(\mathrm{n}=601)$ that were ethnically matched [20].

The rs12249854 minor allele (A) frequency was higher $(5.8 \%)$ in the $\mathrm{AD}$ group as compared to the controls (3.9\%), however, this was not significant $(\mathrm{P}=0.0668$, Chi-squared test, allelic odds ratio $=1.5(95 \% \mathrm{CI}=0.97$ 2.3)) (Table 1). In addition to looking at the allele frequencies we also looked at genotype specific effects. The AA genotype is rare and was not observed in the control group. While two AA individuals were seen in the $\mathrm{AD}$ group, this was not significant $(\mathrm{P}=0.0648$, Chi squared test). Because the expected minor allele frequency is low, the Chi-squared test may be unreliable therefore we implemented 1,000,000 permutations using PLINK [36] for both allelic (empirical $P=0.079$ ) and genotypic (empirical $\mathrm{P}=0.051$ ) models. Assuming perfect linkage disequilibrium between the genotyped and functional SNP and a multiplicative risk model, our sample was $80 \%$ powered to detect a heterozygous genotype relative risk of 1.8 with a type I error of $0.5 \%$ [37]. The APOE $\varepsilon 4$ allele is a major risk factor for LOAD therefore we also stratified our samples by presence or absence of the $\varepsilon 4$ allele. The minor allele frequency was $5.7 \%$ and $5.6 \%$ in the $\varepsilon 4$ and non- $\varepsilon 4$ group respectively. Although not significant, it is interesting to note that both $\mathrm{AA}$ individuals were also homozygous for the $\varepsilon 4$ allele.

\section{Discussion}

LOAD is a major cause of dementia and is becoming increasingly important in ageing populations. Identifying the genetic susceptibility factors may help to identify those at risk of developing the disease and the effective targeting of future preventative treatments. With the exception of $A P O E$, no genes have been conclusively shown to be susceptibility factors for LOAD. In this study, we genotyped a panel of $\mathrm{AD}$ patients and looked for an

Table I: Statistical analysis of HECTD2 marker rs 12249854

\begin{tabular}{cllll}
\hline rs I 2249854 & AD n (\%) & Controls n (\%) & $\begin{array}{l}\text { P-value } \\
\text { (Chi-square) }\end{array}$ & $\begin{array}{l}\text { P-value } \\
\text { (PLINK) }\end{array}$ \\
\hline AA & $2(0.6)$ & $0(0.0)$ & 0.0648 & 0.051 \\
TA & $33(10.3)$ & $47(7.8)$ & & \\
TT & $285(89.1)$ & $554(92.2)$ & 0.0668 & 0.079 \\
A & $37(5.8)$ & $47(3.9)$ & & \\
T & $603(94.2)$ & $1155(96.1)$ & &
\end{tabular}

P-values were calculated using a chi-squared test and as an alternative we also implemented I,000,000 permutations using PLINK [36]. http:// pngu.mgh.harvard.edu/purcell/plink/ 
association with a HECTD2 SNP previously shown to be associated with prion disease [20]. Although the minor allele frequency was higher in the $\mathrm{AD}$ samples than the controls this was not significant. This result suggests that in spite of being a promising candidate, HECTD2 is not implicated in $\mathrm{AD}$. Although a negative study, our data do not totally exclude HECTD2. Our study assumes that, as for prion disease, a common variant of HECTD2 is the susceptibility allele. However, multiple rare variants would not be detectable by our tagging SNP. Re-sequencing of HECTD2 in a panel of AD samples would be required to exclude this possibility.

LOAD has a complex aetiology and collections of patient samples may be highly heterogeneous, therefore, very large sample sizes may be required to detect small effects. The heterogeneity of the disease phenotype and the varying inclusion criteria used in different studies may contribute to the difficulties in replicating promising findings from different centres.

Prevalence figures suggest that LOAD affects $20 \%$ of people aged 75-84 years and rising in older age groups [1]. No detailed age information was available for our control group, however, samples were taken from current blood donors which suggests that although currently unaffected by dementia it is likely that a significant proportion will develop $\mathrm{AD}$ later in life and are therefore likely to carry susceptibility alleles. This may confound our findings. Large cohorts of non-demented elderly individuals are difficult to obtain, however, their use would increase the power to detect genetic susceptibility factors.

Several studies have reported evidence for a LOAD susceptibility locus on Chr 10q, however, the exact locations vary and the regions are frequently broad with added uncertainty about the number of genes involved. It is hoped that results from large, well controlled and replicated GWAS studies will successfully identify the susceptibility alleles on Chr 10q and at other loci across the genome.

\section{Conclusion}

Based on linkage data, association with another neurodegenerative disease and association with the ubiquitin-proteosome system, HECTD2 is a promising candidate susceptibility factor for LOAD. In this study we have genotyped a panel of $\mathrm{AD}$ patients for the HECTD2 SNP rs12249854 (A/T) and compared this data to a previously genotyped control population. The minor allele (A) frequency was increased (5.8\%) compared to controls $(3.9 \%)$, however, this was not statistically significant. We were unable to exclude weak or moderate effects on $\mathrm{AD}$ risk. No differences were seen when the population was further stratified by APOE $\varepsilon 4$ genotype. Based on this data we conclude that the common variants of HECTD2, as detected by our tagging SNP, are unlikely to be strong susceptibility factors for LOAD in the UK population.

\section{Competing interests}

The authors declare that they have no competing interests.

\section{Authors' contributions}

Research was planned by SEL and JC. Genotyping was carried out by SEL. Patients were assessed and samples provided by MR and NR. Analysis of data was done by SEL and SM. The manuscript was written by SEL, SM and JC. All authors read and approved the final version of the manuscript.

\section{Acknowledgements}

This study would not have been possible without the generous support of patients, their families and carers and referring physicians. Some of this work was undertaken at University College London Hospital, which received a proportion of funding from the Department of Health's NIHR Biomedical Research Centres funding scheme. We are also grateful to the UK National Blood Service for access to UK blood donors; James Uphill and Mark Poulter for preparation and maintenance of human DNA and Gary Adamson for APOE typing. This work was funded by the Medical Research Council, UK.

\section{References}

I. Ferri CP, Prince M, Brayne C, Brodaty H, Fratiglioni L, Ganguli M, Hall K, Hasegawa K, Hendrie H, Huang YQ, Jorm A, Mathers C, Menezes PR, Rimmer E, Scazufca M: Global prevalence of dementia: a Delphi consensus study. Lancet 2005, 366:2II2-2II7.

2. Glenner GG, Wong CW: Alzheimers-Disease and Downs-Syndrome - Sharing of A Unique Cerebrovascular Amyloid Fibril Protein. Biochem Biophys Res Commun 1984, I 22: I I31-I I 35

3. Grundke-lqbal I, Iqbal K, Quinlan M, Tung YC, Zaidi MS, Wisniewski HM: Microtubule-Associated Protein-Tau - A Component of Alzheimer Paired Helical Filaments. J Biol Chem 1986, 26 I:6084-6089.

4. Goate A, Chartier-Harlin M-C, Mullan M, Brown J, Crawford F, Fidani L, Giuffra L, Haynes A, Irving N, James L, Raeber AJ: Segregation of a missense mutation in the amyloid precursor protein gene with familial Alzheimer's disease. Nature 1991, 349:704-706.

5. Levy-Lahad E, Wasco W, Poorkaj P, Romano DM, Oshima J, Pettingell WH, Yu CE, Jondro PD, Schmidt SD, Wang K, Crowley AC, Fu Y-H, Guenette SY, Galas D, Nemens E, Wijsman EM, Bird TD, Schellenberg GD, Tanzi RE: Candidate gene for the chromosome I familial Alzheimer's disease locus. Science 1995, 269:973-977.

6. Sherrington R, Rogaev El, Liang Y, Rogaeva EA, Levesque G, Ikeda M, Chi H, Lin C, Li G, Holman K, Tsuda T, Mar L, Foncin J-F, Bruni AC, Montesi MP, Sorbi S, Rainero I, Pinessi L, Nee L, Chumakov I, Pollen D, Brookes A, Sanseau P, St George-Hyslop PH: Cloning of a gene bearing missense mutations in early-onset familial Alzheimer's disease. Nature 1995, 375:754-760.

7. Gatz M, Reynolds CA, Fratiglioni L, Johansson B, Mortimer JA, Berg $S$, Fiske A, Pedersen NL: Role of genes and environments for explaining Alzheimer disease. Arch Gen Psychiatry 2006, 63(2): $168-74$

8. Strittmatter WJ, Saunders AM, Schmechel D, Pericak Vance M, Enghild J, Salvesen GS, Roses AD: Apolipoprotein E: high-avidity binding to beta-amyloid and increased frequency of type 4 allele in late-onset familial Alzheimer disease. Proc Natl Acad Sci USA 1993, 90:1977-1981.

9. Daw EW, Payami H, Nemens EJ, Nochlin D, Bird TD, Schellenberg GD, Wijsman EM: The number of trait loci in late-onset Alzheimer disease. Am J Hum Genet 2000, 66:196-204.

10. Waring SC, Rosenberg RN: Genome-wide association studies in Alzheimer disease. Arch Neurol 2008, 65:329-334. 
II. Bertram L, Blacker D, Mullin K, Keeney D, Jones J, Basu S, Yhu S, McInnis MG, Go RCP, Vekrellis K, Selkoe DJ, Saunders AJ, Tanzi RE: Evidence for genetic linkage of Alzheimer's disease to chromosome 10q. Science 2000, 290:2302.

12. Myers A, Holmans P, Marshall H, Kwon J, Meyer D, Ramic D, Shears S, Booth J, DeVrieze FW, Crook R, Hamshere M, Abraham R, Tunstall N, Rice F, Carty S, Lillystone S, Kehoe P, Rudrasingham V, Jones L, Lovestone S, Perez-Tur J, Williams J, Owen MJ, Hardy J, Goate AM: Susceptibility locus for Alzheimer's disease on chromosome 10. Science 2000, 290:2304.

13. Ertekin-Taner N, Graff-Radford N, Younkin LH, Eckman C, Baker M, Adamson J, Ronald J, Blangero J, Hutton M, Younkin SG: Linkage of plasma $A$ beta 42 to a quantitative locus on chromosome 10 in late-onset Alzheimer's disease pedigrees. Science 2000 , 290:2303.

14. Hamshere ML, Holmans PA, Avramopoulos D, Bassett SS, Blacker D, Bertram L, Wiener H, Rochberg N, Tanzi RE, Myers A, Vrieze FWD, Go R, Fallin D, Lovestone S, Hardy J, Goate A, O'Donovan M, Williams J, Owen MJ: Genome-wide linkage analysis of 723 affected relative pairs with late-onset Alzheimer's disease. Hum Mol Gen 2007, 16:2703-27I2.

15. Vekrellis K, Ye Z, Qiu WQ, Walsh D, Hartley D, Chesneau V, Rosner MR, Selkoe DJ: Neurons regulate extracellular levels of amy loid beta-protein via proteolysis by insulin-degrading enzyme. J Neurosci 2000, 20: I657-1665.

16. Jones L, Abraham R, Myers A, DeVrieze FW, Hamshere MV, Thomas HM, Marshall H, Compton D, Spurlock G, Turic D, Hoogendorn B, Kwon JM, Petersen RC, Tanaglos E, Norton J, Morris JC, Bullock R, Liolitsa D, Lovestone S, Hardy J, Goate A, O'Donovan M, Williams J, Owen MJ: Substantial linkage disequilibrium across the insulin degrading enzyme locus but no association with late-onset Alzheimer's disease. Hum Genet 200I, 109(6):646-52.

17. Ertekin-Taner N, Allen M, Fadale D, Scanlin L, Younkin L, Petersen RC, Graff-Radford N, Younkin SG: Genetic variants in a haplotype block spanning IDE are significantly associated with plasma A beta 42 levels and risk for Alzheimer disease. Hum Mutat 2004, 23:334-342.

18. Nowotny P, Hinrichs AL, Smemo S, Kauwe JSK, Maxwell T, Holmans P, Hamshere M, Turic D, Jehu L, Hollingworth P, Moore P, Bryden L, Myers A, Doil LM, Tacey KM, Gibson AM, McKeith IG, Perry RH, Morris CM, Thal L, Morris JC, O'Donovan MC, Lovestone S, Grupe A, Hardy J, Owen MJ, Williams J, Goate A: Association studies between risk for late-onset Alzheimer's disease and variants in insulin degrading enzyme. Am J Med Genet $B$ Neuropsychiatr Genet 2005, 136B(I):62-8.

19. Ait-Ghezala G, Abdullah L, Crescentini R, Crawford F, Town T, Singh $S$, Richards D, Duara R, Mullan M: Confirmation of association between DI0S583 and Alzheimer's disease in a case-control sample. Neurosci Lett 2002, 325:87-90.

20. Lloyd SE, Maytham EG, Pota H, Grizenkova J, Molou E, Uphill J, Hummerich $\mathrm{H}$, Whitfield J, Alpers MP, Mead S, Collinge J: HECTD2 is associated with susceptibility to mouse and human prion disease. PLoS Genet 2009, 5:e 1000383 .

21. Collinge J: Prion diseases of humans and animals: their causes and molecular basis. Annu Rev Neurosci 200I, 24:5 I 9-550.

22. Mead S: Prion disease genetics. Eur J Hum Genet 2006 , | 4:273-28|.

23. Palmer MS, Dryden AJ, Hughes JT, Collinge J: Homozygous prion protein genotype predisposes to sporadic Creutzfeldt-Jakob disease. Nature 1991, 352:340-342.

24. Collinge J, Palmer MS, Dryden AJ: Genetic predisposition to iatrogenic Creutzfeldt-Jakob disease. Lancet I99I, 337:144|-|442.

25. Mead S, Stumpf MP, Whitfield J, Beck J, Poulter M, Campbell T, Uphill J, Goldstein D, Alpers MP, Fisher E, Collinge J: Balancing selection at the prion protein gene consistent with prehistoric kurulike epidemics. Science 2003, 300:640-643.

26. Stephenson DA, Chiotti K, Ebeling C, Groth D, DeArmond SJ, Prusiner SB, Carlson GA: Quantitative trait loci affecting prion incubation time in mice. Genomics 2000, 69:47-53.

27. Lloyd S, Onwuazor ON, Beck J, Mallinson G, Farrall M, Targonski P, Collinge J. Fisher E: Identification of multiple quantitative trait loci linked to prion disease incubation period in mice. Proc Natl Acad Sci USA 200I, 98:6279-6283.

28. Manolakou K, Beaton J, McConnell I, Farquar C, Manson J, Hastie ND, Bruce M, Jackson IJ: Genetic and environmental factors modify bovine spongiform encephalopathy incubation period in mice. Proc Natl Acad Sci USA 200I, 98:7402-7407.

29. Mead S, Poulter M, Uphill J, Beck J, Whitfield J, Webb TE, Campbell T, Adamson G, Deriziotis P, Tabrizi SJ, Hummerich H, Verzilli C, Alpers MP, Whittaker JC, Collinge J: Genetic risk factors for variant Creutzfeldt-Jakob disease: a genome-wide association study. Lancet Neurol 2009, 8:57-66.

30. Prusiner SB, Scott MR, DeArmond SJ, Cohen FE: Prion protein biology. Cell 1998, 93:337-348.

31. Ciechanover A, Brundin P: The ubiquitin proteasome system in neurodegenerative diseases. Sometimes the chicken, sometimes the egg. Neuron 2003, 40:427-446.

32. Hegde AN, Upadhya SC: The ubiquitin-proteasome pathway in health and disease of the nervous system. Trends Neurosci 2007 , 30:587-595.

33. Goldberg AL: On prions, proteasomes, and mad cows. $N$ EnglJ Med 2007, 357: II50-1152.

34. Kitada $T$, Asakawa $S$, Hattori $N$, Matsumine $H$, Yamamura $Y$, Minoshima S, Yokochi M, Mizuno Y, Shimizu N: Mutations in the parkin gene cause autosomal recessive juvenile parkinsonism. Nature 1998, 392:605-608.

35. Hixson JE, Vernier DT: Restriction isotyping of human lipoprotein $E$ by gene amplification and cleavage with Hhal. J Lipid Res 1990, $31: 545-548$.

36. Purcell S, Neale B, Todd-Brown K, Thomas L, Ferreira MAR, Bender D, Maller J, Sklar P, de Bakker PIW, Daly MJ, Sham PC: PLINK: a toolset for whole-genome association and population-based linkage analysis. Am J Hum Genet 2007, 8 I:559-575.

37. Purcell S, Cherny SS, Sham PC: Genetic Power Calculator: design of linkage and association genetic mapping studies of complex traits. Bioinformatics 2003, 19:149-150.

\section{Pre-publication history}

The pre-publication history for this paper can be accessed here:

http://www.biomedcentral.com/1471-2350/10/90/pre pub

Publish with Biomed Central and every scientist can read your work free of charge

"BioMed Central will be the most significant development for disseminating the results of biomedical research in our lifetime. "

Sir Paul Nurse, Cancer Research UK

Your research papers will be:

- available free of charge to the entire biomedical community

- peer reviewed and published immediately upon acceptance

- cited in PubMed and archived on PubMed Central

- yours - you keep the copyright 